\title{
1,4-BENZOQUINONES IN AFRICAN MILLIPEDS ${ }^{1}$
}

\author{
By J. Smolanoff, ${ }^{2}$ J. M. Demange, ${ }^{3}$ J. Meinwald, ${ }^{2}$ T. Eisner ${ }^{4}$
}

The defensive glands of millipeds have been the subject of considerable recent chemical and biological investigation. Compounds identified from the secretions have included hydrogen cyanide, acetate esters, aldehydes, phenols, I,4-benzoquinones, quinazolinones, and nitrogen-containing terpenes (references in Eisner et al., 1975). The most widespread of these components are the I,4-benzoquinones which have been found in the secretion of species of the orders Julida, Spirobolida, and Spirostreptida. We here report the isolation of I,4-benzoquinones from three species of Spirostreptida from Africa: Archispirostreptus tumuliporus, Peridontopyge conani, and P. rubescens.

The millipeds were collected in Senegal, in the region of Kaolack (Sine-Saloum), where they are known to damage agricultural crops, particularly peanuts. Peridontopyge conani and P. rubescens can be especially abundant. At the beginning of the rainy season the millipeds swarm over the soil surface in large numbers in search of food and mates.

The animals were shipped live to Ithaca, N. Y., where they were "milked" of secretions on arrival. Individual animals were handled and tapped gently with a small metal mallet, until the golden-brown secretion oozed from their glands. The effluent was soaked up in pieces of filter paper, and transferred to carbon disulfide. Examination of the secretion from the two species of Peridontopyge by gasliquid chromatography ( $6 \mathrm{ft}$. column, $\left.15 \% \mathrm{SE}-30,200^{\circ} \mathrm{C}\right)$ revealed the presence of a single component. Comparison with an authentic sample (gas-liquid chromatography, infrared spectroscopy, proton magnetic resonance spectroscopy) showed this component to be 2methyl-3-methoxy-I,4-benzoquinone.

The secretion from $A$. tumuliporus was shown by gas-liquid chromatography to contain two components, which by chromatographic and spectroscopic comparison with authentic samples were shown to

\footnotetext{
${ }^{1}$ Paper No. XLIV of the series Defense Mechanisms of Arthropods.

${ }^{2}$ Department of Chemistry, Spencer T. Olin Laboratory, Cornell University, Ithaca, New York 14853.

${ }^{3}$ Muséum National d'Histoire Naturelle, Laboratoire de Zoologie, 61 Rue de Buffon, Paris - Ve.

${ }^{4}$ Section of Neurobiology and Behavior, Division of Biological Sciences, Cornell University, Ithaca, New York 14853.
}

Manuscript received by the editor April 3, 1975 
be 2-methyl-3-methoxy-I,4-benzoquinone and 2-methyl-1,4-benzoquinone. Gas-liquid chromatography indicated the presence of a third minor component, present as a shoulder on the downward side of the 2-methyl-I,4-benzoquinone peak.

Individual milkings from males and females of the three species showed no qualitative sexual differences in quinone content, although the ratio of the two quinones in $A$. tumuliporus showed considerable individual variability.

The two quinones here identified are the most common ones found in millipeds (references in Eisner et al., I975). Fifteen spirostreptoid species have been previously studied. Of these, eight resemble Archispirostreptus tumuliporus in that they produce both quinones (Archispirostreptus gigas, Cambala hubrichti, Collostreptus fulvus, Doratogonus annulipes, Orthoporus flavior, O. punctilliger, Prionopetalum frundsbergi, $P$. tricuspis) (Eisner et al., I975; Perissé and Salles, 1970; Wood, 1974). One species resembles Peridontopyge conani and $P$. rubescens in that it produces 2-methyl-3-methoxy-1,4-benzoquinone only (Orthoporus conifer) (Eisner et al., 1965). Five species, including two other Peridontopyge, produce only 2-methyl-1,4benzoquinone (Auglonopygus aculeatus, Peridontopyge aberrans, $P$. vachoni, Spirostreptus multisulcatus, Rhapidostreptus (Spirostreptus) virgator) (Barbier, 1959; Barbier and Lederer, 1957). One species produces the unsubstituted quinone, I,4-benzoquinone (Spirostreptus castaneus) (Barbier and Lederer, I957).

This study has been supported by grants AI-02908 from the National Institutes of Health and BMS-74-I5084 from the National Science Foundation.

\section{ReFERENCES Cited}

BARBIER, M.

1959. Séparations de $p$-benzoquinones naturelles par chromatoplaques. J. Chromatography 2, 649-651.

BARBIER, M. AND LEDERER, E.

1957. On the benzoquinones of the venom of three species of myriapods. Biokhimya 22, 221-225.

Eisner, T., Alsop, D., Hicks, K., and Meinwald, J.

1975. Defensive secretions of millipeds. In "Arthropod Venoms" (S. Bettini, ed.). Springer Verlag (in press).

Eisner, T., Hurst, J. J., Keeton, W. T., and Meinwald, Y.

1965. Defense mechanisms of arthropods. XVI. Para-benzoquinones in the secretion of spirostreptoid millipeds. Ann. Ent. Soc. Amer. $58,247-248$. 
Perissé, A. C. M., and Salles, C. A.

1970. Estudo químico de Diplopoda Brasileiros. III. Collostreptus fulvus (Schubert, 1960). Atlas So'c. Biol. Rio de Janeiro 13, 95-99.

WoOD, W. F.

1974. Toluquinone and 2-methoxy-3-methyl benzoquinone from the defensive secretions of three African millipeds. Ann. Ent. Soc. Amer. 67, 988-989. 

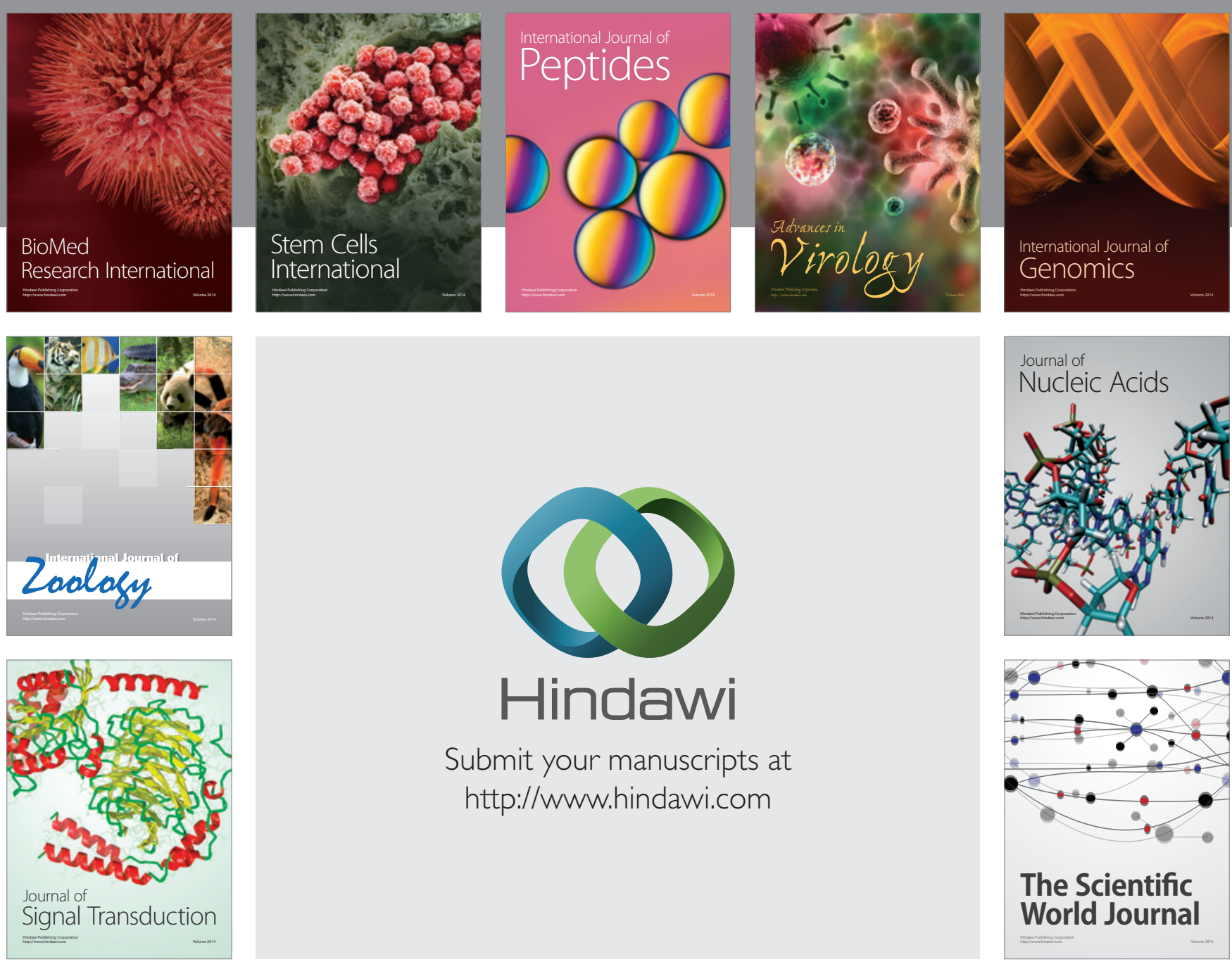

Submit your manuscripts at

http://www.hindawi.com
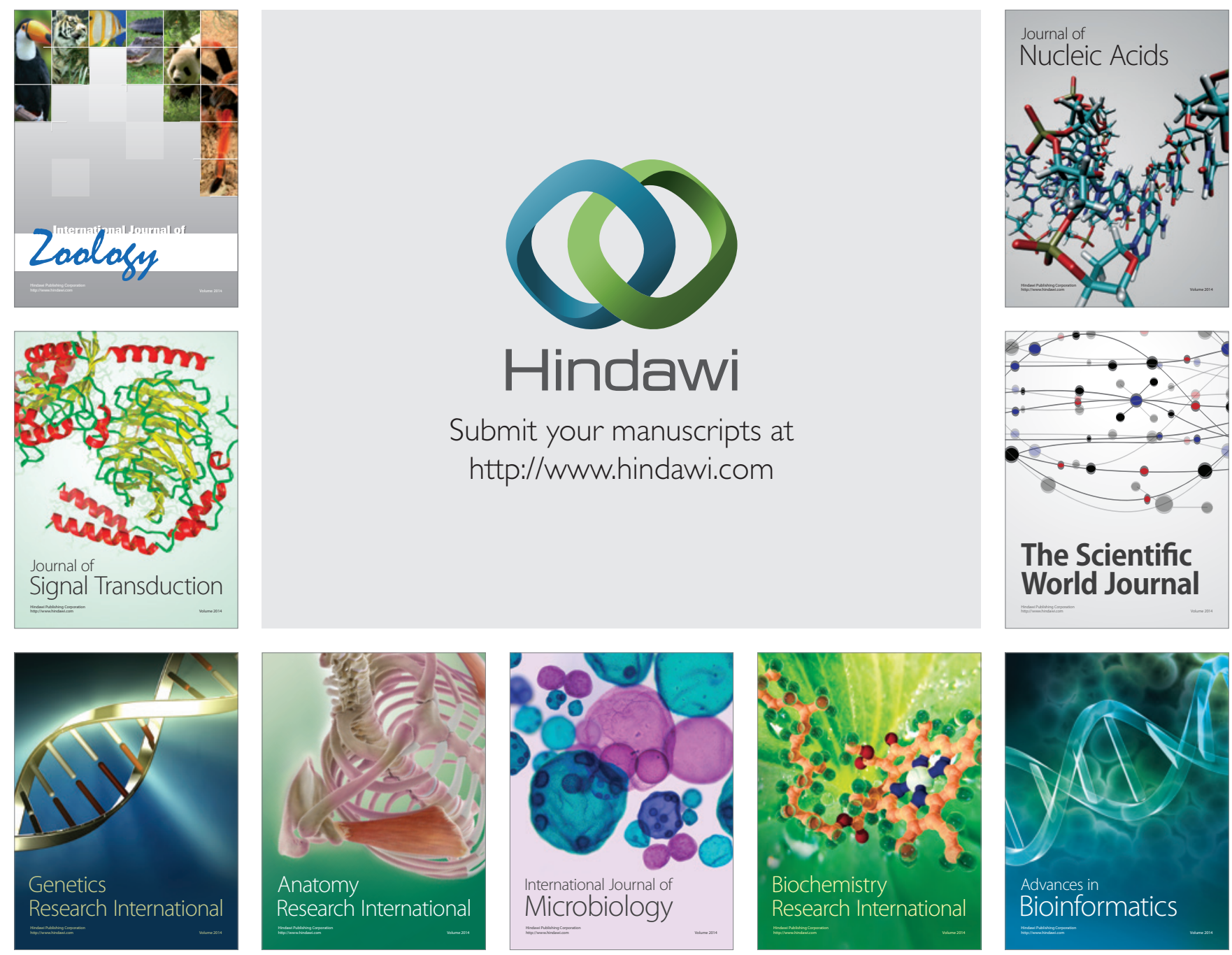

The Scientific World Journal
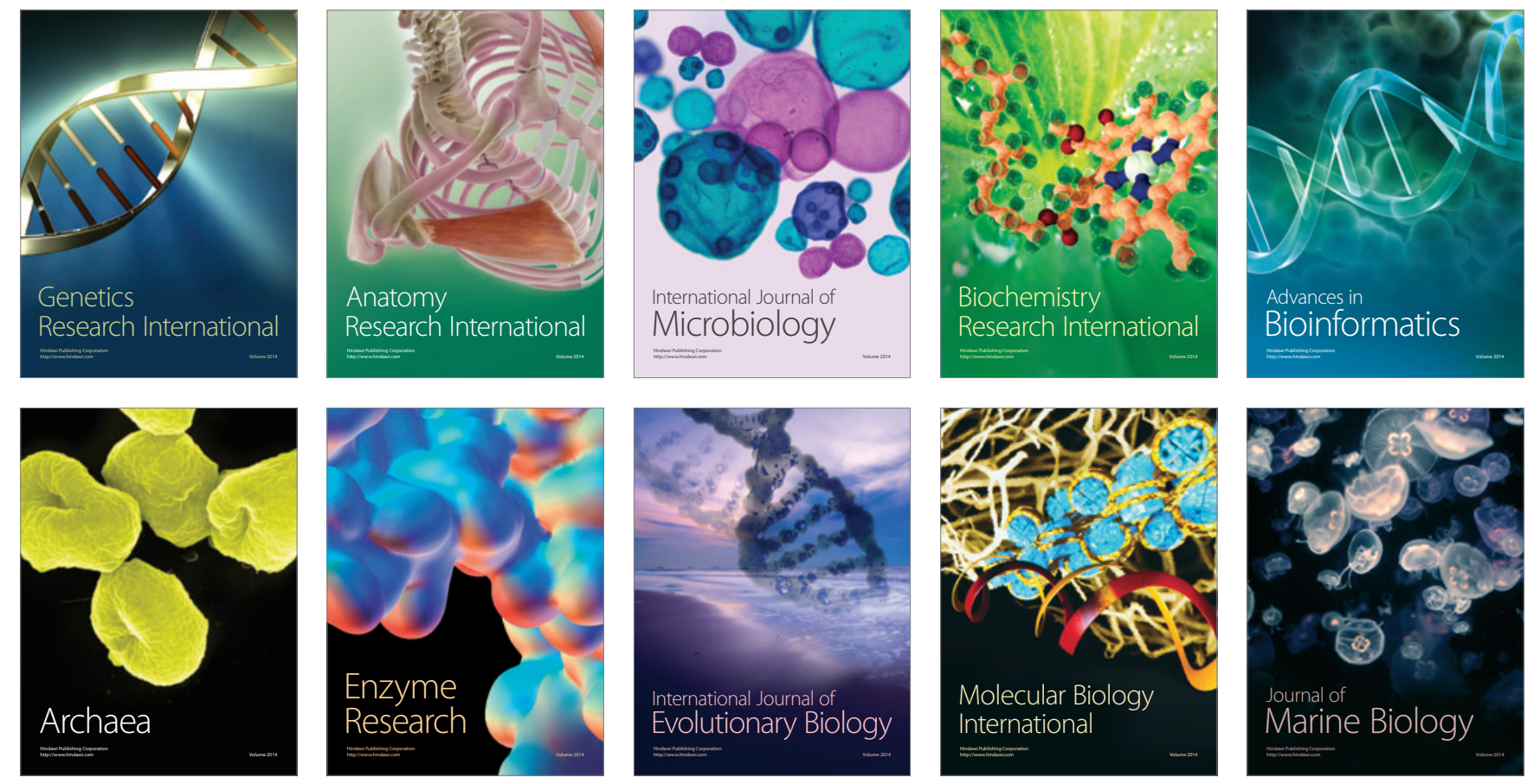